\title{
Література
}

1. Варналій 3. С. Основи підприємницької діяльності. Підручник для учнів 10-11 кл. / 3. С. Варналій, В. О. Сизоненко. - К. : Знання, 2004. - 404 с. 2. Вачевський М. В. Основи економіки. Навч. пос. для 10-11 кл. / М. В. Вачевський, В. М. Мадзігон. - К. : Педагогічна думка, 2007. - 612 с. 3. Кремень В. Г. Освіта у XXI столітті / В. Г. Кремень. Шлях освіти, 2003. - № 2. - С. 2-4. 4. Кулішов В. В. Основи ринкової економіки. / В. В. Кулішов, О. С. Подалка, М. В. Вачевський / за ред. В.В.Кулішова. - Львів: Магнолія, 2013. - 472 с. 5. Кулішов В. В. Економічний довідник підприємця/ В. В. Кулішов. - Львів: Магнолія, 2009. - 162 с. 6. Кулішов В. В. Основи економічної теорії / В. В. Кулішов. - Львів : Магнолія плюс, 2007. - 516 с. 7. Левківський К. М. Збірник нормативних актів щодо Болонського процесу / Уклад.: Левківський К. М., Логвін 3. І., Губерська Н. Л. - К. : ПТЗО, 2008. - 120 с. 8. Михасюк I. Р. Українське підприємництво в умовах глобалізації / I. Р. Михасюк, І. М. Бернадський. - Львів : Видав. центр ЛНУ ім. Івана Франка, 2008. - 56 с. 9. Петрович Й. М. Організація підприємництва в Україні. / Й. М. Петрович, Г. М. Захарчин, А. А. Теребух. - Львів : Оксарт, 2000. -320 c.

Тетяна Мелкумова

\section{ВИВЧЕННЯ ПРИКМЕТНИКІВ НА ЗАНЯТТЯХ З УКРАЇНСЬКОЇ МОВИ ЯК ІНОЗЕМНОЇ НА І КУРСІ}

Мелкумова Т. В. Вивчення прикметників на заняттях $з$ української мови як іноземної на I курсі.

У статті запропоновано низку завдань для актуалізації, поглиблення, систематизації, узагальнення та закріплення знань іноземних студентів I курсу про граматичні категорії прикметників, сполучуваність прикметників з іменниками. Подано методику вивчення розрядів прикметників за значенням і ступенів порівняння якісних прикметників.

Ключові слова: прикметник, тверда група, м’яка група, ступені порівняння.

Мелкумова Т. В. Изучение имён прилагательных на занятиях по украинскому языку как иностранному на I курсе.

В статье предложена серия заданий для актуализации, углубления, систематизации, обобщения и закрепления знаний иностранных студентов I курса о грамматических категориях имён прилагательных. Подана методика изучения разрядов имён прилагательных по значению и степеней сравнения качественных прилагательных.

Ключевые слова: имя прилагательное, твёрдая группа, мягкая группа, степени сравнения.

Melkumova T. W. Studying the adjectives on Ukrainian as foreign language lessons for the first-course students.

The article deals with the set of tasks for actualization, intensification, systematization, generalization and consolidation of foreign students' knowledge about grammar adjective categories and combination of adjectives and nouns. The methods of studying the meaning adjective categories and degrees of comparison of qualitative adjectives are given.

Key words: adjective, hard group, soft group, degrees of comparison. 
У Сдиній типовій навчальній програмі 3 української мови для студентівіноземців [5] приділяється значна увага роботі над словом як одиницею морфологічного рівня мовної системи на початковому й основному етапах навчання.

Загалом теоретичні засади навчання морфології розроблені такими науковцями, як О. Біляєв, В. Горяний, Н. Грипас, В. Мельничайко, М. Плющ, М. Шкільник й ін. Нині стрімкими темпами накопичується досвід щодо особливостей використання як традиційних, так і нестандартних підходів до вивчення морфології в школах нового типу (О. Горошкіна, В. Горяний, С. Караман й ін.). Активно досліджуються актуальні проблеми порівняльної методики викладання мов (А. Акішина, О. Біляєв, А. Богуш, В. Вагнер, Т. Вишнякова, Л. Вознюк, С. Голобородько, О. Каган, В. Костомаров, Г. Михайловська, С. Ніколаєва, О. Падучева, Н. Пашківська, М. Пентилюк, К. Пучко, О. Хорошковська).

Лінгводидактика пропонує різноманітні методи та прийоми викладання української мови й іноземним студентам $[1 ; 4 ; 6 ; 10]$. Актуальність досліджень визначається сучасними вимогами, спрямованими на вдосконалення національної системи освіти та розширення культурних зв'язків між країнами. Ці обставини певною мірою зумовлюють зміни соціальної мотивації засвоєння української мови як іноземної та необхідність оптимізації технологій іiі навчання, зокрема формування граматичної компетенції як складника комунікативної компетенції в різних видах мовленнєвої діяльності.

Методика мови має певний доробок з викладання теми «Прикметник» студентаміноземцям. Під час підготовки до занять 3 цієї теми можна використовувати значний досвід роботи 3 українськими школярами та студентами [3; 7; 9.]. На жаль, комплексний порадник щодо вивчення прикметників з іноземними студентами відсутній. Недостатнє висвітлення питання в теорії та методиці навчання української мови як іноземної, низький рівень навичок відмінювання прикметників, утворення ступенів порівняння спонукали до розроблення низки взаємопов'язаних завдань 3 вивчення теми «Прикметник» на I курсі, маніфестація якої є метою статті. Матеріал може бути використаний під час повторення на II і III курсах.

Підгрунтя для оволодіння українською мовою формується під час навчання на підготовчому факультеті для іноземних громадян: студенти розрізнюють роди іменників, визначають число перших засвоєних лексем, утворюють форми роду присвійних займенників і прикметників, засвоюють особові закінчення дієслів теперішнього часу, отримують уявлення про дієвідміни тощо.

На початку I курсу знання студентів-іноземців з української мови актуалізуються та поглиблюються. Зокрема, на заняттях, присвячених вивченню прикметника, слід узагальнити й систематизувати засвоєне студентами про утворення числових і родових форм; роз'яснити відмінності в утворенні відмінкових форм прикметниками твердої та м'якої груп; розвивати вміння та формувати навички правильного використання в мовленні відмінкових форм прикметників. Згодом слід приділити увагу розрядам прикметників за значенням й утворенню форм ступенів порівняння якісних прикметників, виробленню навичок оперування такими формами в мовленні. Загалом до теми «Прикметник» на I курсі пропонується обладнання: таблиці циклу «Відмінювання прикметників», таблиця «Ступені порівняння»; роздавальний матеріал граматичні вправи, тексти художніх творів (В. Сухомлинський «Найласкавіші руки», В. Симоненко «Найогидніші очі порожні...»); перекладні й орфографічні словники.

Щодо роботи з теоретико-граматичним матеріалом зауважимо: протягом заняття всі визначення спершу озвучуються викладачем, згодом студенти читають їх 3 методичного посібника й відтворюють. Теоретичні відомості мають бути місткими, 
ілюструватися словами, зрозумілими студентам; не варто подавати приклади, що потребують тлумачення чи перекладу, оскільки це певним чином переобтяжує визначення та відволікає від розуміння його змісту. Нові слова бажано вводити під час роботи $з$ текстами, щоб іноземні студенти могли сприймати лексеми й з урахуванням їхніх синтаксичних функцій. Це полегшує студентам-іноземцям подальше оперування новими словами.

На етапі актуалізації знань про прикметник студенти виконують різні види робіт. По-перше, повторюють визначення прикметника як частини мови: «Прикметники слова, що виражають ознаки предметів і відповідають на питання який? ([чоловік] веселий, вродливий), чий? ([журнал] се́стрин, ба́тьків); яка? ([жінка] весела, вродлива), чия? ([книга] се́стрина, ба́тькова); яке? ([хлоп'я] веселе, вродливе), чиє? ([фото] се́стрине, ба́тькове); які? ([діти] веселі, вродливі), чиї? ([речі] се́стрині, ба́тькові)». Подруге, міркують над запитанням «Чому ця частина мови називається саме «прикметник»?

Далі студенти шукають 3-поміж поданих слів прикметники, добирають до них питання: Украйна, украӥнський; шевченківський, Шевченко; по-французькому, франиузьке; криворізька, Кривий Ріг; швидкі, швидко; старий, старіти. Добре сприймають студенти загадки на зразок: 1) За поданими ознаками впізнайте предмет і запишіть його назву: Червоне, кругле, солодке. Сучасне, велике, шумне. Дерев'яний, письмовий. Маленька, зелена. Довгий, пасажирський, швидкий. Старе, високе, зелене. Широке, блакитне, чисте; 2) Знайдіть зайве слово: Солоний, цікавий, солодкий, великий, комфорт, довгий. Київський, російський, китайський, короткий, львівський. Зелений, високий, рожевий, білий, синій. Веселий, сумний, смачний, серйозний, хоробрий. Жовтий, сподіватися, коханий, любий, милий, ненависний. На яку спільну ознаку Ви орієнтувалися? Продовженням завдань може бути пропозиція скласти самостійно 5 аналогічних загадок / 3 аналогічні ряди слів.

Щаблинкою до наступного етапу заняття про сполучуваність прикметників 3 іменниками є завдання: 3'ясуйте, до яких частин мови належать слова: син, хімічний, срібне, площинна, веселі, село, золоте, ввічлива, старанні, похмурий, радісна, поет, щзаслива, повільний, тенісист, гарне, київський, вінницька, поганий, дощова, світлий, темне, друг, нова, солодкі, добрий, шоколад, дерев'яні, залізні, світле, крейда, художник, формула, дощ. За результатами виконання цього завдання студенти заповнюють таблицю:

\begin{tabular}{|c|c|c|c|c|c|}
\hline \multicolumn{2}{|c|}{ Іменник } & \multicolumn{4}{|c|}{ Прикметник } \\
\hline Хто? & Що? & Який? & Яка? & Яке? & Які? \\
\hline & & & & & \\
\hline
\end{tabular}

Викладач нагадує студентам, що змінювання прикметника за родами та числами залежить від форм іменника, з яким прикметник узгоджується (веселий хлопець - весела дівчина - веселе свято - веселі діти), і пропонує правильно поєднати слова в таких стовпчиках:

$\begin{array}{llll}\text { смачне } & \text { морозиво } & \text { розумний } & \text { студентка } \\ \text { дорогий } & \text { бібліотекар } & \text { сумлінна } & \text { книга } \\ \text { дешева } & \text { комп'ютер } & \text { відома } & \text { кімната } \\ \text { веселі } & \text { сумка } & \text { чсті } & \text { декан } \\ \text { сумний } & \text { студенти } & \text { брудна } & \text { руки. }\end{array}$


Варто виконати завдання на зразок: 1) Доберіть потрібний іменник. Допишіть речення. Визначте рід прикметників: У мого друга високий ... . У мене велика ... . Коло будинку росте старе.... 2) Утворіть словосполучення 3 поданих іменників і прикметників: Високий (будинок, людина, дерево, оцінки); криворізький (вокзал, студентка, населення, вулиці); іноземний (студент, мова, свято, міста). Наприклад: чистий (одяг, дошка, вікно, зошити) - чистий одяг, чиста дошка, чисте вікно, чисті зошити.

Актуалізацію знань про відмінювання прикметників варто здійснювати за допомогою таблиць. Таблиці важливі для опрацювання, узагальнення й систематизації граматичних відомостей; робота 3 таблицями увиразнює процес навчання, забезпечує глибше засвоєння матеріалу [13].

На етапі роботи над відмінковими формами прикметників викладач демонструє студентам, як відмінюються прикметники твердої групи, які у формі називного відмінка мають закінчення -ий, $-a$, -e:

\begin{tabular}{|c|c|c|c|c|c|}
\hline \multirow{2}{*}{\multicolumn{2}{|c|}{ Відмінки }} & \multicolumn{3}{|c|}{ Однина } & \multirow{2}{*}{ Множина } \\
\hline & & чоловічий рід & жіночий рід & середній рід & \\
\hline \multicolumn{2}{|c|}{ Н. в. } & дорогий & дорога & дороге & дорогі \\
\hline \multicolumn{2}{|c|}{ P. в. } & дорогого & дорогої & дорогого & дорогих \\
\hline \multicolumn{2}{|c|}{ Д. в. } & дорогому & дорогій & дорогому & дорогим \\
\hline \multirow{2}{*}{ Зн. в. } & кого? & \multirow{2}{*}{$\begin{array}{l}\text { дорогого } \\
\text { дорогий }\end{array}$} & \multirow{2}{*}{ дорогу } & \multirow{2}{*}{ дороге } & \multirow{2}{*}{$\begin{array}{l}\text { дорогих } \\
\text { дорогі }\end{array}$} \\
\hline & що? & & & & \\
\hline \multicolumn{2}{|c|}{ Op. в. } & дорогим & дорогою & дорогим & дорогими \\
\hline \multicolumn{2}{|c|}{$\begin{array}{c}\text { М. в. } \\
(H a, y, b)\end{array}$} & $\begin{array}{l}\text { дорогому } \\
\text { дорогім }\end{array}$ & дорогій & $\begin{array}{l}\text { дорогому } \\
\text { дорогім }\end{array}$ & дорогих \\
\hline
\end{tabular}

Усно та письмово відмінюють студенти словосполучення: теплий день, тепла погода, тепле сонце, теплі стосунки; новий студент, нова подруга, нове завдання, нові ідеї; рідний брат, рідна школа, рідне місто, рідні люди; гарний блокнот, гарна студентка, гарне фото, гарні друзі.

Особливості відмінювання прикметників м'якої групи, які у формі називного відмінка мають закінчення -ї̆, -їй, -я, -є, наприклад: середній (рівень), учорашня (прогулянка), учорашнє (завдання), також відображені в таблиці:

\begin{tabular}{|c|c|c|c|c|c|}
\hline \multirow{2}{*}{\multicolumn{2}{|c|}{ Відмінки }} & \multicolumn{3}{|c|}{ Однина } & \multirow{2}{*}{ Множина } \\
\hline & & чоловічий рід & жіночий рід & середній рід & \\
\hline \multicolumn{2}{|c|}{ H. в. } & вечірній & вечірня & вечірне & вечірні \\
\hline \multicolumn{2}{|c|}{ P. в. } & вечірнього & вечірньої & вечірнього & вечірніх \\
\hline \multicolumn{2}{|c|}{ Д. в. } & вечірньому & вечірній & вечірньому & вечірнім \\
\hline \multirow{2}{*}{ Зн. в. } & кого? & \multirow{2}{*}{$\begin{array}{c}\text { вечірнього } \\
\text { вечірній }\end{array}$} & \multirow{2}{*}{ вечірню } & \multirow{2}{*}{ вечірне } & \multirow{2}{*}{$\begin{array}{l}\text { вечірніх } \\
\text { вечірні }\end{array}$} \\
\hline & що? & & & & \\
\hline \multicolumn{2}{|c|}{ Op. в. } & вечірнім & вечірньою & вечірнім & вечірніми \\
\hline \multicolumn{2}{|c|}{$\begin{array}{c}\text { М. в. } \\
(H a, y, b)\end{array}$} & $\begin{array}{c}\text { вечірньому } \\
\text { вечірнім }\end{array}$ & вечірній & $\begin{array}{c}\text { вечірньому } \\
\text { вечірнім }\end{array}$ & вечірніх \\
\hline
\end{tabular}


Усно та письмово виконують студенти завдання: 1) Визначте рід і відмінок прикметників у реченнях: У мой кімнаті нові меблі: м'яке ліжко, велике крісло, дерев'яний письмовий стіл, книжкова шафа. У мене велика кімната. Я люблю сидіти у м'якому кріслі. На изьому високому дереві маленьке листя. На білій стіні плакат. Мій тато слухає джазову музику. Викладач пише чорною ручкою. Рашида називають старанним студентом. За круглим столом сидять першокурсники. Вона пите веселий вірш; 2) Уставте потрібне слово в речення: На столі лежить ... хліб. Брату дали ... птаха. У студентки ... портфель. Дідусь - ... ... студент пише вправу. Він сидить на ... стільиі. У нас ... родина. Ахмед..., а його брат ... . Дніпро-... річка. Слова для довідки: широка, старий, свіжий, важкий, маленький, новий, старанний, велика, товстий, худий; 3) Провідміняйте словосполучення: домашній одяг, домашня робота, домашнє свято, домашні справи; ранній час, рання зустріч, раннє побачення, ранні гості; синій колір, синя ручка, сине море, сині аркуші; осінній настрій, осіння погода, осінне небо, осінні парки.

Окреме заняття варто присвятити з'ясуванню розподілу прикметників за розрядами за значенням i морфологічними ознаками. Розуміння студентами особливостей якісних, відносних i присвійних прикметників закладає підвалини адекватному використанню їх у мовленні та коректному утворенню форм ступенів порівняння. Цей етап роботи можна розпочати з вивчення присвійних прикметників, а завершити розглядом якісних задля зв'язку зі складним граматичним матеріалом заняття про ступені порівняння якісних прикметників.

Викладач пропонує студентам 3'ясувати, які ознаки виражають такі групи прикметників: 1) червоний, солоний, легкий, прямокутний (колір, смак, вага, форма); 2) мідний, зимовий, ранковий, икільний (матеріал, пора року, час доби, призначення); 3) братова [подруга], батьків [портфель], жайворонкова [пісня] (належність кого, чого-небудь людині чи тварині). Як висновок має прозвучати теза про розподіл прикметників на розряди за значенням.

Читання з поясненням допоможе згадати студентам, у яких життєвих ситуаціях їм доводилося чути присвійні прикметники: Сьогодні до нас прийде Богданова дружина Олена [дружсиа Богдана - Богданова дружина]. Дивись! Там Петрик. А от і Петриків дідусь [дідусь Петрика- Петриків дідусь]. Лесиного собаку сьогодні вигулює ї брат [собака Лесі-Лесин собака].

Пояснення викладача - лаконічне: «Присвійні прикметники називають ознаку за належністю особі (людині / тварині) й відповідають на питання чий? Оксанин гаманець, материн блокнот; чия? Оксанина кімната, материна ласка; чиє? Оксанине фото, материне дзеркало; чиї? Оксанині речі, материні черевики».

Після висвітлення викладачем особливостей творення присвійних прикметників студенти виконують завдання: 1) Знайдіть присвійні прикметники у словосполученнях: Людмилина книга, велика кімната, дерев'яний стіл, Ахмедова ручка, батьків голос, другий курс, мамина пісня, старий університет, братова дружина; 2) Утворіть іменники від прикметників: доччин, свекрушині, Надї̈, батьків, пташина, невістчине, товаришів, братове, синів, Миколина, лікареві, Настин; 3) Утворіть присвійні прикметники від поданих слів: а) підпис батька, будинок лікаря, книжка сестри; б) Олена, студент, сусід, Мухамед. Спробуйте дібрати до таких прикметників антоніми - чи можливо це? Останнє питання може стосуватися й такої групи слів: скляна (ваза), актовий (зал), спортивна (база), масажний (кабінет), медовий (аромат), лижна (прогулянка), піщаний (берег), дорожня (валіза), глиняний (глечик). 
Так викладач знайомить студентів із відносними прикметниками, пояснюючи: «Відносні прикметники виражають ознаку предмета за відношенням до матеріалу (дубовий - дуб, скляний- скло, дерев'яний- дерево, сталевий- сталь); до особи (студентський - студент, читацький - читач); до явища (вітряний - вітер); до часу (учорашній- вчора); до місця (міський- місто). У словосполученнях відносні прикметники можна замінити іншими словами, наприклад, торговельний майданчикмайданчик для торгівлі». За цим зразком студентам пропонується виконати аналогічні трансформації таких словосполучень: алюмінієва виделка, озоновий шар, підземний хід, харківська вулиия, міський майдан, дніпровський міст, дерев 'яний стілець, карпатське повітря, морські хвилі, золота каблучка, діамантові прикраси. «Чи можливо дібрати до цих прикметників антоніми?»- питання є щаблинкою до наступного етапу заняття, присвяченого вивченню якісних прикметників, розгляд яких варто почати з виконання однієї із вправ: 1) Знайдіть антоніми: чистий, гарний, довгий, холодний, короткий, новий, брудний, широкий, великий, прямий, поганий, старий, солодкий, чужий, вузький, цікавий, рідний, нудний, малий, солоний, кривий, теплий; 2) Доберіть антоніми до прикметників у таких словосполученнях: гарячий чай, темна кімната, хороший фільм, маленьке місто, иікава книжка, важке завдання, довге пальто, старша сестра, стара річ, стара людина; 3) Доберіть антоніми до прикметників новий, нова, нове, нові, великий, велика, велике, великі, світлий, світла, світле, світлі, пізній, пізня, пізнє, пізні, холодний, холодна, холодне, холодні. Умова: антонім повинен належати до тієї ж групи (твердої чи м'якої), що й поданий прикметник, мати аналогічні форми роду й числа, наприклад: присутній - відсутній, присутня - відсутня, присутне- відсутне, присутні-відсутні.

Після характеристики викладачем важливих ознак якісних прикметників студенти виконують вправи на закріплення вмінь розрізнювати розряди прикметників: 1) Доберіть по два прикметники до кожного іменника: Київ, молодь, сад, вода, поле, долина, ліс, учень, письменник, дружба, мир, місто, пісня; укажіть, які $з$ прикметників якісні, які - відносні; заповніть таблицю:

\begin{tabular}{|l|l|l|}
\hline \multicolumn{1}{|c|}{ Іменник } & \multicolumn{1}{|c|}{ Якісний прикметник } & \multicolumn{1}{|c|}{ Відносний прикметник } \\
\hline Київ & сучасний & привокзальний \\
\hline молодь & ввічлива & криворізька \\
\hline сад & & \\
\hline
\end{tabular}

2) Розподіліть словосполучення на три групи, до складу кожної з яких належать, відповідно, якісні, відносні або присвійні прикметники: сумна пісня, дерев'яний стіл, лікарів рецепт, веселе обличчя, золотий перстень, Андріїв телефон, скляний посуд, яскрава особистість, пташине гніздо, кам'яна стіна, усміхнена дівчинка, залізний дах, холодна погода, каштанове дерево, тітчине взуття, тривожний настрій, дядьків будинок, вишневий цввіт, Лідї̈н конспект, вишнева скатертина, Петрів зошит.

«Особливістю якісних прикметників, - зазначає викладач, - $€$ їхня здатність утворювати форми ступенів порівняння. Адже ознака предмета може виявлятися звичайною мірою (холодний день: $+3^{\circ} \mathrm{C}$ ), більшою мірою (холодніший день: $\left.-5^{\circ} \mathrm{C}\right) \mathrm{i}$ найбільшою мірою (найхолодніший день: $-21^{\circ} \mathrm{C}$ ). Прочитайте діалоги: 1) - Яка чудова погода. - Так, найкраща. 2) - Це більш легка вправа. - Так, вона найлегша. - А ия? - Це дуже складна, найскладніша в книжиі». Правила утворення форм ступенів порівняння якісних прикметників студенти засвоюють під час коментування викладачем таблиці: 


\begin{tabular}{|c|c|c|c|c|c|c|}
\hline \multirow{2}{*}{$\begin{array}{l}\text { Початкова } \\
\text { форма } \\
\text { прикмет- } \\
\text { ника }\end{array}$} & \multicolumn{2}{|c|}{$\begin{array}{ll}\text { Вищий } & \text { ступінь } \\
\text { порівняння } & \end{array}$} & \multicolumn{4}{|c|}{ Найвищий ступінь порівняння } \\
\hline & $\begin{array}{l}\text { Проста } \\
\text { форма }\end{array}$ & $\begin{array}{l}\text { Скла- } \\
\text { дена } \\
\text { форма }\end{array}$ & $\begin{array}{l}\text { Проста } \\
\text { форма }\end{array}$ & $\begin{array}{l}\text { Складна } \\
\text { форма }\end{array}$ & $\begin{array}{l}\text { Складена } \\
\text { форма }\end{array}$ & $\begin{array}{l}\text { Описовий } \\
\text { зворот }\end{array}$ \\
\hline & $\begin{array}{l}\text { основа } \\
\text { якісного } \\
\text { прикмет- } \\
\text { ника } \\
+ \\
-u-, \text {-iu- }\end{array}$ & $\begin{array}{l}\text { більш, } \\
\text { менши } \\
+ \\
\text { якісний } \\
\text { прикмет- } \\
\text { ник }\end{array}$ & $\begin{array}{l}\text { най- } \\
+ \\
\text { проста } \\
\text { форма } \\
\text { вищого } \\
\text { ступеня }\end{array}$ & $\begin{array}{l}\text { як, щуо } \\
+ \\
\text { проста } \\
\text { форма } \\
\text { вищого } \\
\text { ступеня }\end{array}$ & $\begin{array}{l}\text { найбільи, } \\
\text { найменш } \\
+ \\
\text { якісний } \\
\text { прикмет- } \\
\text { ник }\end{array}$ & $\begin{array}{l}\text { від усіх, } \\
\text { за всіх } \\
+ \\
\text { проста } \\
\text { форма } \\
\text { вищого } \\
\text { ступеня } \\
\text { порівнян-ня }\end{array}$ \\
\hline швидкий & швидиий & $\begin{array}{l}\text { більши } \\
\text { швидкий, } \\
\text { менши } \\
\text { швидкий }\end{array}$ & $\begin{array}{l}\text { най- } \\
\text { швид- } \\
\text { иий }\end{array}$ & $\begin{array}{l}\text { якнай- } \\
\text { швидии } \\
\check{u}, \\
\text { щуонай- } \\
\text { швидиии } \\
\check{u}\end{array}$ & $\begin{array}{l}\text { найбільши } \\
\text { швидкий, } \\
\text { наймении } \\
\text { швидкий }\end{array}$ & $\begin{array}{l}\text { швидший } \\
\text { за всіх, } \\
\text { швидший } \\
\text { від усіх }\end{array}$ \\
\hline
\end{tabular}

Задля вироблення вміння правильно утворювати форми ступенів порівняння студенти працюють із якісними прикметниками добрий, світлий, широкий, білий, чорний, теплий, холодний, гарячий, темний, милий, розумний, духмяний, ціккавии, гучний, нудний, худий, заповнюючи таблицю:

\begin{tabular}{|c|c|c|c|c|c|c|}
\hline \multirow{2}{*}{$\begin{array}{c}\text { Початкова } \\
\text { форма } \\
\text { прикмет- } \\
\text { ника }\end{array}$} & \multicolumn{2}{|c|}{$\begin{array}{c}\text { Вищий ступінь } \\
\text { порівняння }\end{array}$} & \multicolumn{4}{|c|}{ Найвищий ступінь порівняння } \\
\hline & $\begin{array}{c}\text { Проста } \\
\text { форма }\end{array}$ & $\begin{array}{c}\text { Скла- } \\
\text { дена } \\
\text { форма }\end{array}$ & $\begin{array}{l}\text { Проста } \\
\text { форма }\end{array}$ & $\begin{array}{c}\text { Складна } \\
\text { форма }\end{array}$ & $\begin{array}{c}\text { Складена } \\
\text { форма }\end{array}$ & $\begin{array}{c}\text { Описов } \\
\text { ий } \\
\text { зворот }\end{array}$ \\
\hline
\end{tabular}

Викладач звертає увагу студентів на особливості творення форм ступенів порівняння певними прикметниками: 1) наявність паралельних форм: тонкий - тонший $i$ тонкіший, грубий- грубший $i$ грубішиц̆, тихий- тихший $i$ тихімий, здоровийздоровший $i$ здоровіший; 2) випадіння -к-, -ок-, -ек-: рідкий-рідший, легкий-легший, глибокий - глибший, далекий - дальший; 3) зміни приголосних: а) $c+u=щ$ : високий-

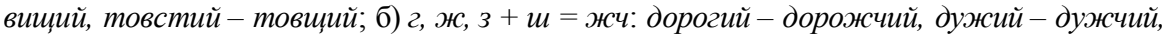
важкий - важчий, тяжкий - тяжчий, близький - ближчий, низьки - нижчий, вузькийвужчий (виняток: довгий - довший); 4) суплетивні форми: гарний - кращий, поганийгірший, малий-менший, великий-більший, добрий-ліпший.

Варто ознайомити студентів із групами якісних прикметників, що не утворюють форми ступенів порівняння: віддієслівні прикметники невблаганний, незбагненний, невмирущий, непохитний; слова з суфіксами батьківський, біленький, жовтуватий, величезний; сталі ознаки сліпий, глухий, босий, мертвий, німий, голий, ворожий; колір за схожістю кремовий, вишневий, шоколадний, лимонний; масть тварин карий, вороний; складні прикметники червонобокий, чорноокий, світло-зелений, яскраво-червоний.

Для формування навички грамотного утворення форм ступенів порівняння прикметників студенти виконують завдання: 1) Замініть просту форму ступеня порівняння прикметників складеною: Мій брат високий, але я щуе вищий (к $\rightarrow$ щ). У мойй 
кімнаті низька стеля, а у твоїй ще нижча (зьк $\rightarrow$ жч). Вони сидять на високому стільці, а ми на найвищому. У нас найвеселіша група. У мойй кімнаті широкі двері, а у твойй ширші. У нього чорне волосся, а в мене чорніше. У мене важкий портфель, але твій важчий. [Він купив свіжий хліб.] Я теж, але у нього хліб свіжіший. Наприклад: Ця річка вузька, але струмок вужчий. - Ця річка вузька, але струмок більш вузький. 2) Складіть речення $з$ прикметниками-антонімами товстий-худий, веселий-сумний, поганийгарний, високий - низький; утворіть від прикметників форми ступенів порівняння.

Використання ступенів порівняння прикметників у мовленні можна проілюструвати також під час роботи 3 художніми творами (оповідання Василя Сухомлинського «Найласкавіші руки», вірш Василя Симоненка «Найогидніші очі порожні...»). Після прослуховування та прочитання творів студенти вибирають із текстів прикметники (разом із означуваними словами), визначають їх число, рід, групу, відмінок, форму ступеня порівняння.

Наступним етапом у вивченні прикметників $є$ виділення їх у зв'язному тексті за фахом, визначення при цьому граматичних категорій прикметників, а також виконання вправ трансформаційного характеру. Наприклад: «Прочитайте текст. Випишіть прикметники. Форму однини прикметників замініть формою множини. Просту форму вищого або найвищого ступеня порівняння прикметників замініть складеною формою». Під час виконання таких завдань робота над словом як структурним елементом морфологічного рівня мовної системи є дієвим чинником поглиблення знань і мовного розвитку іноземних студентів. Навчальний матеріал для занять з української мови варто поєднувати 3 матеріалом інших вишівських дисциплін, звертаючи при цьому увагу на засвоєння змістового компонента.

\section{Література}

1. Азарова Л. С. Українська мова для слухачів-іноземців підготовчого відділення : збірник вправ і завдань : [навч. посібник] / Л. Є. Азарова, І. Є. Зозуля, Л. В. Солодар. Вінниця : ВНТУ, 2010. - 121 с. 2. Бахтіярова Х. Ш. Українська мова : практичний курс для іноземців : посібник для слухачів підготовчих відділень i факультетів / Х. Ш. Бахтіярова, С. С. Лукашевич, I. З. Майданюк й ін. - Тернопіль : Укрмедкнига, 1999. - 320 с. 3. Білецька О. Українська мова : комплексна підготовка до зовнішнього незалежного оцінювання / О. Білецька, I. Житар, Т. Матвійчук. Тернопіль : Підручники і посібники, 2013. - 576 с. 4. Бойко І. О. Практичний курс української мови для іноземців : [навч. посібник] / I. О. Бойко, М. В. Бондар. - К. : Вид. центр КНЛУ, 2012. - 228 с. 5. Єдина типова навчальна програма з української мови для студентів-іноземців основних факультетів нефілологічного профілю вищих навчальних закладів України III-IV рівнів акредитації / Уклад. : Л.І.Дзюбенко, В. В. Дубічинський, С. А. Чезганов та ін. ; за ред. О. Н. Тростинської, Н. І. Ушакової. К. : НТУУ «КПІ», 2009. - 52 с. 6. Зайченко Н. Ф. Практичний курс української мови для іноземців : усне мовлення / Н. Ф. Зайченко, С. А. Воробйова. - К. : Знання України, 2005. - 324 с. 7. Караман С. О. Практикум 3 методики навчання української мови / С. О. Караман, О. В. Караман, О. М. Горошкіна й ін. ; за ред. М. І. Пентилюк. К. : Ленвіт, 2003. - 302 с. 8. Лисенко Н. О. Українська мова для іноземних студентів : навч. посібник / Н. О. Лисенко, Р. М. Кривко, С. І. Світлична, Т. П. Цапко ; за ред. С. М. Смоленського. - К. : Центр учбової літератури, 2010. - 240 с. 9. Методика навчання української мови в середніх освітніх закладах / З. П. Бакум, І. В. Гайдаєнко, О. М. Горошкіна та ін. ; за заг. ред. М. І. Пентилюк. - К. : Ленвіт, 2005. - 400 с. 10. Тишковець М. Використання таблиць у вивченні української мови як іноземної / Марія Тишковець // Теорія і практика викладання української мови як іноземної. - 2008. - Вип. 3. - С. 262-268. 